\title{
Human dignity and the best interest of the child
}

\author{
Catrian M. Sotelo, M.D. ${ }^{a}$ \\ Collaborator: Alejandro Barceló M.D. ${ }^{b}$
}

\begin{abstract}
In our daily medical practice, we are constantly facing situations that require a comprehensive view of the patient, based not only on scientific knowledge, butalsoencompassing relevant legal, anthropological, philosophical, and sociological concepts. This can be summarized by saying that bioethical knowledge and training are critical in current professional practice. This will allow us to provide quality care while contributing to a paradigm change in health sciences. The objective of this article is to review concepts such as person, dignity, and best interests of the child, and reflect on the importance we give to them in our professional practice.

Key words: dignity, human rights, child, defense of the child.

http:/ / dx.doi.org/10.5546/ aap.2021.eng.e113
\end{abstract}

To cite: Sotelo CM. Human dignity and the best interest of the child. Arch Argent Pediatr 2021;119(2):e113-e116.

a. Associated Professor of the Chair of Bioethics, University Institute of Health Sciences (Instituto Universitario de Ciencias de la Salud, IUCS), H.A. Barceló Foundation, School of Medicine.

b. Lawyer, Professor of the Chair of Bioethics, IUCS, H.A. Barceló Foundation, School of Medicine. Buenos Aires, Argentina.

E-mail address:

Catrian M. Sotelo, M.D.: catrisotelo@gmail.com

Funding:

None.

Conflict of interest: None.

Received: 1-17-2020

Accepted: 10-5-2020

\section{INTRODUCTION}

The best interests of the child (BIC) are generally believed to be undefined guidelines, subject to multiple legal and psychosocial interpretations, which serve as a basis to take decisions on the fringes of currently recognized rights. On the contrary, the BIC imply the full realization of their rights. ${ }^{1}$ This statement is true and allows to reconsider the rights of the child as a tool to limit and guide authorities' actions in particular and adults' actions in general. ${ }^{2}$ In order to foster an active reflection and remember that children deserve respect, the realization of their rights, and additional protection due to their vulnerability, this article will review essential bioethical concepts focused on their application in medical practice.

\section{Definitions of person}

This section will introduce two concepts regarding the definition of person: both from an ontological and a legal perspective. Ontologically speaking, a person is defined as a rational substance endowed with knowledge and will who is a master of their acts. ${ }^{3}$ From a legal standpoint, a person is someone who is capable of acquiring rights and assuming obligations. ${ }^{4}$ Surrounded by both dimensions of thought, bioethics acts as a general life ethics. ${ }^{5}$

For practical purposes, bioethics schools of thought may be classified into two big groups:

Personalist schools: ${ }^{6}$ This group includes principlism, personalism, and the followers of humanism, who state that a person is an end in itself. Dignity is an inherent characteristic of a person, as an ontological feature, which is inalienable, unquantifiable, and intrinsic, and does not depend on other conditions, such as freedom, possession of goods or relationship life.

Transpersonalist schools: ${ }^{7}$ Utilitarianism is the main representative of this school, but radical liberalism and social Darwinism may also be included. From this point of view, personal rights and dignity may be put aside in some situations, based on a proportionality judgment regarding when it is legal to do so. A person's dignity depends on their autonomy, will, life quality/value, biological characteristics, and relationship life.

It is evident that the distinction between both groups is not rigid, given that in different situations a 
school can prove to be more relevant when reflecting on reality. According to Diego Gracia, "it is impossible to treat all human beings as ends all the time; we all are means to something or someone at some point. What is immoral is being treated as means without considering that we are beings endowed with dignity". ${ }^{8}$ Therefore, having dignity is what distinguishes people from substance not considered as such.

\section{What is dignity, then?}

Etymologically, the word comes from the Latin dignus, meaning "equal, of the same price or value" or "that which is fair and/or worthy of respect". In religion, this translates into imago Dei, "the mediator between the creator and creation". ${ }^{9}$

In ethics, dignity is an intrinsic quality of human nature that is the basis of all the person's rights. In addition, it has a personal basis, since each person can define it; it has a social basis, in relation to social objectives that are achieved over time; and it is grounded in freedom and the ability to distinguish between pleasure and pain, and choose accordingly. ${ }^{10}$

Kant posits that you should "act as to treat humanity, whether in thine own person or in that of any other, in every case as an end withal, never as a means only". However, according to him, dignity obeys a personal law, i.e. human beings obey their conscience and, to this end, autonomy is critical. ${ }^{11}$ According to Hegel, human beings are persons for having reason and freedom: dignity is exclusively reserved for those who have conscience and freedom. ${ }^{12}$

At present, in the same line of thought, Carlos Nino posits that "dignity is grounded in will and influenced by the autonomy principle" ${ }^{\prime \prime}{ }^{13}$ and Dworkin claims that rights warrant the protection of minorities by majority groups, but in order to achieve this protection, individuals must have freedom. ${ }^{14}$ Therefore, the relation between dignity and freedom shows how the protection of dignity is represented in legal requirements regarding freedom. A certain degree of reductionism can be observed in these authors, given that according to them, having freedom and the autonomy principle determine the dignity of a human being.

Robert Alexy, in his publication Human Dignity and Proportionality Analysis, ${ }^{15}$ states that it makes sense to interfere with human dignity when there are fair reasons. This leads to the distinction of justified and unjustified interferences with human dignity. However, when defining dignity, the author lists the characteristics required for having it, which include intelligence, sentiment, and consciousness, the latter being the pivotal condition.

The previously mentioned authors consider autonomy as a necessary condition for the expression of dignity. In this regard, there are differences between those who have complete autonomy and those who are not able to fully express it, such as children.

\section{Are children persons?}

The International Convention on the Rights of the Child (1959), which is one of the treaties that were incorporated to Argentina's National Constitution in 1994, together with the Universal Declaration of the Rights of the Child, recognizes children as persons and subjects of law. The Argentine Civil Code adheres to the National Constitution and the international treaties incorporated to it. The national case law reaffirms the described items. ${ }^{2}$

\section{What are the best interests of the child?}

First of all, it is important to remember what the rights of the child are. These are human rights endowed with more effective protection mechanisms, with priority or supremacy for belonging to a vulnerable group. ${ }^{16}$ They complement the general mechanisms of rights recognized to all human beings, but this additional protection is not autonomous but based on general legal protection.

Another important aspect is that the rights of the child go beyond cultures and societies, set minimum rules that are not the expression of a particular culture, and regulate the correct behavior of all people. This allows them to be incorporated to different national constitutions.

The BIC are a guiding principle to ensure this protection that supports the fact that the rights of the child should allow to exercise other rights and solve conflicts between them. ${ }^{17}$ Although the BIC definition is well known, it has different legal and social interpretations. In order to resolve these differences and unify criteria, it is necessary to bear in mind that the rights of the child are human rights -applied to specific situations this group faces through life- that order relations and set care priorities in the child-family-State triad: while parents exercise their parental responsibility (not parental authority, thanks to Articles 5 and 12 of the Convention on the Rights of the Child), the State regulates and guarantees the realization of the 
rights of the child by supporting parents so that the child can fully develop their rights, but by no means does it allow these parental rights to be absolute. In this direction, it is also possible to regulate social conflicts, given that the BIC allow to make priority visible when dealing with collective interests, where childhood falls into the background for being a minority. ${ }^{18}$

\section{What is the scope of application of the rights of the child and the best interests of the child in health care?}

First of all, a consultation is an opportunity to get to know the child's situation and intervene adequately. It is important to be aware of the tools at our disposal in order to do so. No matter if the child has health insurance, the Argentine State guarantees the access to childhood health care programs coordinated by the National Ministry of Health and incorporated to provinces and jurisdictions.

The Mother and Child Plan (2010) establishes the health coverage of the mother during pregnancy and labor up to the first month after birth, and the health care coverage of the newborn infant until one year of age. Also, the FamilyCentered Maternity Care Program proposed by the World Health Organization (2011) sees the child as part of a family. ${ }^{19}$

In outpatient care, following with the primary health care strategy, well-child exams of children without health insurance are taken into consideration in plans NACER (2005) and SUMAR (2012). The REMEDIAR plan (2002) enables access to medication and, by means of Act 27491, the National Immunization Schedule introduces a policy to control vaccine-preventable diseases. ${ }^{20}$

In the school setting, the National School Health Program (Programa Nacional de Salud Escolar, PROSANE) (Act 26061, 2015) allows to screen children for health problems and put them in contact with the appropriate health care level. ${ }^{21}$ The National Program for Comprehensive Adolescent Health (2007) is based on a comprehensive health approach for adolescents and warrants confidentiality and treatment according to the degree of autonomy of this particular group. ${ }^{22}$

For children with conditions requiring hospitalization, the national law stipulates the hospitalization of the child with their family and health care provided by childhood specialists. In addition, children can continue school in the hospital setting, given that, since 1946, hospital teaching depends on the National Ministry of Education. One example of this is Hospital School N. ${ }^{\circ} 1$ of Hospital de Niños Ricardo Gutiérrez. ${ }^{23}$

Lastly, for patients with special needs or incurable diseases, a palliative care strategy (National Palliative Care Program, 2016), the introduction of alternative medicine, and the possibility of providing care to their family are taken into consideration. Act 27742 for a Death with Dignity is available for children with endstage diseases. ${ }^{24}$ From a legal standpoint, the Argentine Civil Code regulates legal relations and provides a framework for all these actions based on the National Constitution and treaties adopted.

\section{With all these tools available, which is the paradigm?}

Despite having knowledge of applicable laws and tools in practice, the adequate interpretation of the rights of the child is permeated by modernity and the liberal and utilitarian sociocultural revolution, which have set the tone that the value of life is related to autonomy and productive capacity. In particular, children form a mistake-prone group because of the fine line between their autonomy, their parents' (or guardians') autonomy, and the State.

In order to solve this situation, it is worth remembering that the BIC are globally and particularly linked to psychological, educational, social, legal, environmental, and resource needs of the child and for the child, and that these needs are rights that are incorporated in the International Human Rights Instruments and the Argentine National Constitution. Knowing them, championing them, and letting patients know that we will actively choose their best interest is our main task.

Moreover, acknowledging progressive autonomy and taking decisions in line with bioethical principles in all spheres of pediatric care is one of the essential aspects of comprehensive care and the humanization of health care. This description reveals the paradigm: recognizing childhood as a different stage of life and being natural champions of this cause.

\section{CONCLUSION}

A person is a being endowed with dignity. This characteristic serves as the basis of the different schools of thought in bioethics. The distinction is not rigid, and actions may have one or another foundation in different situations: 
what cannot be done is to ignore human dignity.

Children are people and require respect as such. Nevertheless, they make up a vulnerable group, hence the existence of the BIC to protect them. As professionals, knowing the tools at our disposal and acting in line with this guiding principle is a responsible way of achieving quality care.

The paradigm entails recognizing childhood as a different stage of life and respecting their rights through a comprehensive and humanized health care model. Probably, on many occasions, we will be far from perfection, but it is important to at least reflect frequently on the subject.

\section{REFERENCES}

1. UNICEF. Convención Internacional sobre los Derechos del Niño. Madrid: Unicef; 2015. Page 8.

2. Lanzavecchia G. Interés superior del niñoen el Código Civil y Comercial de la Nación. Sistema Argentino de Información Jurídica. 2018; DACF180248.

3. Martí Andrés G. Sustancia individual de naturaleza racional: el principio personificador y la índole del alma separada. Metafís Pers. 2009; 1:113-29.

4. Herrera M, CarameloG, PicassoS. Código Civily Comercial de la Nación Comentado. 2. ${ }^{a}$ ed. Ciudad Autónoma de Buenos Aires: MINSAL; 2016.

5. Ciuro Caldani MA. Persona humana, filosofía, ética, bioética y derecho. Marzo de 2007. [Accessed on: October $5^{\text {th }}, 2020$ ]. Availableat:http:/ / www.salud.gob.ar/dels/ printpdf/23.

6. García JJ. Bioética personalista y bioética principialista: Perspectivas. Cuad Bioét. 2013; 24(1):67-76.

7. Ortiz Llueca E. Bioética personalista y bioética utilitarista. Cuad Bioét. 2013; 24(1):57-65.

8. Gracia D. Fundamentos de Bioética. 2. ${ }^{\text {a }}$ ed. Madrid: Triacastela; 2007.

9. Flórez RA. El ser humano como imago Dei en Agustín de Hipona: una reflexión a partir delDe trinitate. [Dissertation]. Bogotá: Pontificia Universidad Javeriana; 2014.
10. Macklin R. Dignity is a useless concept. BMJ. 2003. 327(7429):1419-20.

11. KantE. Fundamentación de la metafísica de las costumbres. Madrid: Tecnos; 2006.

12. Hegel F. La ciencia de la lógica. Montevideo: Las cuarenta; 2013.

13. Scatolini J.Dignidad y Autonomía dela Persona, conceptoy fundamento de los derechos humanos. Revista Perspectivas. 2012; 2(1):145-72.

14. Dworkin R. Los derechos en serio. Barcelona: Ariel; 2012.

15. Alexy R. Dignidad humana y Proporcionalidad. Rosario: Universidad; 2015.

16. AZPIRI JO. Derecho a conocer su origen. In: Incidencias del Código Civil y Comercial de la Nación: Derecho de Familia. Buenos Aires: Hammurabi; 2015. Page 197.

17. Lora LN. Discurso jurídico sobre el interés superior del niño. In: Avances de Investigación en Derecho y Ciencias Sociales. X Jornadas de Investigadores y Becarios. Mar del Plata: Ediciones Suárez; 2006. Pages 479-88.

18. Ministerio Público Fiscal de la Nación Argentina. Los derechos de niños, niñas y adolescentes (2012-2017). Buenos Aires: Dirección de relaciones institucionales. 2018. Pages 15-6.

19. Larguía AM, González MA, Solana C, Basualdo MN, et al. Maternidad Segura y Centrada en la Familia [MSCF] con enfoque Intercultural: conceptualización eimplementación del modelo. Buenos Aires: UNICEF; 2012.

20. Argentina.gob.ar. Área de Salud Integral del Niño. [Accessed on: September $30^{\text {th }}$, 2017]. Available at: https: / / www. argentina.gob.ar/salud/dinamia/saludintegral.

21. Argentina.gob.ar. Dirección de Salud Perinatal y Niñez. [Accessed on: June $\left.25^{\text {th }}, 2020\right]$. Available at: https: / / www. argentina.gob.ar/salud/dinamia.

22. Laboratorios Andrómaco. La escuela hospitalaria, una esperanza para el niño internado. Revista Conexión Andrómaco. 2016; 29:8-11.

23. Argentina.gob.ar. El Programa Nacional de Salud Integral en la Adolescencia celebró sus 10 años. [Accessed on: December 1 ${ }^{\text {st }}$ 2017]. Available at: https: / / www.argentina. gob.ar/noticias/el-programa-nacional-de-salud-integralen-la-adolescencia-celebro-sus-10-anos.

24. Blanco LG. Morir con dignidad. DELS. [Accessed on: March 1 $1^{\text {st }}$, 2017]. Available at: http:/ / www.salud.gob.ar/ dels/entradas/morir-con-dignidad. 